\title{
Dry matter, protein, and energy digestibility of diets for juvenile Pacific white leg shrimps (Litopenaeus vannamei) reared at different salinity levels
}

\author{
Yuniel Méndez-Martínez ${ }^{1}$ (i) Milena Gucić ${ }^{2}$ (i) Luis Rafael Martínez-Córdova ${ }^{3}$ (i)

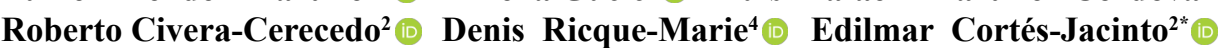

${ }^{1}$ Facultad de Ciencias Pecuarias, Universidad Técnica Estatal de Quevedo (UTEQ), Quevedo, Los Ríos, Ecuador.

${ }^{2}$ Programa de Acuicultura, Centro de Investigaciones Biológicas del Noroeste, S.C. (CIBNOR), La Paz, Baja California Sur, Mexico. E-mail: ecortes04@cibnor.mx. "Corresponding author.

${ }^{3}$ Departamento de Investigaciones Científicas y Tecnológicas (USON), Universidad de Sonora, Hermosillo, Sonora, Mexico.

${ }^{4}$ Universidad Autónoma de Nuevo León, San Nicolás De Los Garza, Nuevo León, Mexico.

ABSTRACT: This study evaluated the effect of low, medium, and high-water salinity (5, 35, and 50 ppt) on the apparent dry matter, protein, and energy digestibility of two formulated and six commercial diets for juvenile whiteleg shrimp, Litopenaeus vannamei, in a 120-day trial. Digestibility was determined in vivo using chromic oxide as an inert diet marker. Hydrostability in pellets varied from $86.8 \%$ to $99.9 \%$; dry matter digestibility varied from $49.1 \%$ to $64.1 \%$; protein digestibility showed greater variations at all salinities (56.9\%-85.8\%); and energy digestibility ranged from 70.1 to $86.4 \%$. Salinity had a significant effect on dry matter, protein, and energy digestibility. Using a principal component analysis (PCA) with a covariance matrix, our findings suggested that the E2 (fishmeal-based formulation) diet and 35 ppt salinity provided optimum hydrostability and digestibility to Pacific white leg shrimp juveniles.

Key words: digestibility, salinity, commercial diets, feed formulation, shrimp.

Digestibilidade da matéria seca, proteína e energia de dietas para camarão juvenil do Pacífico (Litopenaeus vannamei) cultivadas em diferentes níveis de salinidades

RESUMO: Nós medimos o efeito de baixa, normal e alta salinidade (5, 35 e 50ppt) na digestibilidade aparente da matéria seca, proteina e energia em duas dietas formuladas e seis comerciais para camarão juvenil do Pacífico, Litopenaeus vannamei. Os coeficientes de digestibilidade aparente da matéria seca, proteína e energia foram determinados in vivo utilizando o óxido crômico como marcador inerte nas dietas (peso inicial médio de 4g), em um teste de 120 dias. Hidrostabilidade na dieta de 86,8\% a 99,9\%, os coeficientes de digestibilidade da matéria seca variaram de 49,1 a 64,1\%, os coeficientes de digestibilidade da proteína apresentaram maiores variações em todas as salinidades (56,9$85,8 \%$ ), enquanto os coeficientes de digestibilidade da energia variaram de 70,1 a 86,4\%. Efeito significativo da salinidade na digestibilidade da matéria seca, proteína e energia foi encontrado. Esses resultados, usando a análise de componentes principais (PCA) com a matriz de covariância, sugerem que a dieta E2 (fórmula à base de farinha de peixe) e salinidade a 35 ppté ideal para a hidrostabilidade e digestibilidade das dietas para juvenis de camarão-branco-do-Pacífico.

Palavras-chave: dietas comerciais, formulação de ração, camarão.

\section{INTRODUCTION}

The Pacific white leg shrimp Litopenaeus vannamei is one of the most commonly farmed species at commercial scale because of its fast growth, high survival at high density, and resistance to disease (MARTÍNEZ-CÓRDOVA et al., 2009; ANAYA-ROSAS et al., 2017; ABDELRAHMAN et al., 2019). Their osmoregulatory capacity allows them to inhabit waters with salinity ranging from 0.5 to $60 \mathrm{ppt}$ (ROY et al., 2007; JAIME-CEBALLOS et al., 2008; CHEN et al., 2019).
Given the recent increase in market demand, shrimp farming production has shifted from traditional extensive systems toward modern intensive and super-intensive systems. In the latter, environmental regulations require producers to use environmentally-friendly feed sources with low nitrogen and phosphate output (OLAUSSEN, 2018), and reducing waste load to environment (CHATVIJITKUL et al., 2017).

Diet nutrient composition is one of the main factors affecting the digestibility in shrimps; and 
consequently, the waste output in such aquaculture production systems (MARTÍNEZ-CÓRDOVA et al., 2009; CHATVIJITKUL et al., 2017). Diet formulation can; therefore, contribute to minimize waste discharge from aquaculture (AMIRKOLAIE, 2011; MÉNDEZ-MARTÍNEZ et al., 2018).

Studies of feedstuff digestibility in commercially-farmed aquatic organisms have gained increasing interest in recent years (CAMPAÑATORRES et al., 2006; HOSSEIN et al., 2017). Data on nutrient digestibility is particularly important to determine suitable and accurate diet formulations for white leg shrimp farming (YANG et al., 2009; HOSSEIN et al., 2017).

Chemically well-defined diets with high hydrostability enable farmers to reliably predict the animal responses (OBALDO et al., 2002; MÉNDEZMARTÍNEZ et al., 2018; VALENZUELA-COBOS \& VARGAS-FARIAS 2020). Using highly digestible and hydrostable diets is environmentally beneficial, mainly under high density farming where the accumulation of undigested feed contaminates water, increases water treatment costs, and promotes shrimp disease and mortality (OBALDO et al., 2002; AKBARZADEH et al., 2019).

Salinity and temperature are two of the most important environmental factors controlling shrimp growth and survival, as they directly impact their physiological response (BÜCKLE, 2006; KIR et al., 2008; ABDELRAHMAN et al., 2019). If these parameters are controlled within their optimal range, it results in higher farm productivity (PÉREZVELÁZQUEZ et al., 2007; CHEN et al., 2019). The worldwide expansion of low salinity shrimp rearing, driven by increasing demand for this product, requires specific feed formulation for this environment. When shrimp are exposed to low salinity, they need to counteract the passive loss of $\mathrm{Na}^{+}$and $\mathrm{Cl}^{-}$through the active uptake of $\mathrm{Na}^{+}$from water in exchange for $\mathrm{H}^{+}$, which occurs in the apical membrane of osmoregulatory cells (PALACIOS et al., 2004; BÜCKLE, 2006; HURTADO et al. 2006). In arid and semi-arid zones, where high pond water evaporation is common, salinity may increase to $50 \mathrm{ppt}$ or higher, especially by the end of the growing season (PÉREZ-VELÁZQUEZ et al., 2007). Thus environmental and management conditions interfere with the shrimp cultivation system, growth and production performance.

Therefore, this study determined the effect of low, medium, and high salinity on the apparent digestibility of dry matter, protein, and energy of two formulated and six commercial diets for juvenile Pacific white leg shrimp (L. vannamei).

\section{MATERIALS AND METHODS}

\section{Diet formulation and preparation}

Experimental diets (E1 and E2) were formulated (Table 1) with different levels of ingredient inclusion using the MIXIT-WIN software (Agricultural Software Consultants, San Diego, CA, USA). All ingredients were pulverized and sieved through a $250-\mu \mathrm{m}$ mesh. Both experimental diets were prepared by mixing macro-ingredients in a blender until a uniform mixture was obtained. The micro-ingredients (vitamin and mineral premixes, sodium alginate, chromic acid, and antioxidant BHT) were mixed in a plastic container, and then added to the macro-ingredients. Fish oil and soy lecithin were homogenized into an emulsion and added to the mixture. Distilled hot water was added to this mixture ( $\sim 30 \%$ of dry weight of the ingredients), forming a dough, which was then passed through a meat grinder (Torrey $^{\mathrm{MR}}$, Monterrey, Nuevo Leon, MX) to form 2-mm diameter pellets. Then, the pellets were dried in an air flux oven at $45^{\circ} \mathrm{C}$ for $8 \mathrm{~h}$. Finally, the pellets were packed in plastic bags and stored at $-2{ }^{\circ} \mathrm{C}$ until further use (MÉNDEZ-MARTÍNEZ et al., 2017; 2018).

Diet E2 was similar to the commercial fishmeal-based diet formulated according to AKIYAMA et al. (1991) (Table 1), which was first pelletized at an industrial shrimp feed factory (CRUZSUÁREZ et al., 2009); then, it was ground to obtain a maximum particle size of $500 \mu \mathrm{m}$. Subsequently, it was mixed with $1 \%$ chromic oxide as an inert marker and $1 \%$ sodium alginate (A-7128, Sigma, St. Louis, MO, USA) as a high viscosity binder. After that, distilled hot water ( $\sim 30 \%$ of dry weight of the diets) was added to the mixture. The resulting dough was passed through a meat mill (Torrey ${ }^{\mathrm{MR}}$, Monterrey, Nuevo Leon, MX) to form 2-mm diameter holes.

\section{Experimental design}

Juvenile white leg shrimp $(3.6 \pm 0.3 \mathrm{~g})$ were obtained from a local hatchery and transported in 100-L containers to the laboratory of Centro de Investigaciones Biológicas del Noroeste (La Paz, B.C.S., MX). They were acclimated to a salinity of $35 \mathrm{ppt}$ in three 1500-L fiberglass tanks for seven days and fed with commercial feed with $35 \%$ crude protein (PIASA $^{\mathrm{TM}}$, La Paz, BCS, MX). Molts, dead shrimp, and unconsumed feed were removed daily.

A completely randomized $8 \times 3$ (diet $\times$ salinity) factorial experimental design was used, with four replicates per treatment. Treatments consisted of six commercial diets for shrimp (D1, D2, D3, D4, D5, and D6), and the two formulated diets described 
Table 1 - Formulation (g/100 g of dry matter) of the experimental diets (E1 and E2) used to measure in vivo digestibility of dry matter, protein, and energy in juvenile Litopenaeus vannamei shrimp.

\begin{tabular}{|c|c|c|}
\hline \multirow[t]{2}{*}{ Ingredients } & \multicolumn{2}{|c|}{ 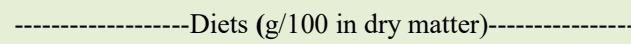 } \\
\hline & E1 & E2 \\
\hline Wheatmeal $^{1}$ & 45.6 & 45.14 \\
\hline Sardinemeal $^{1}$ & 22.8 & 34.0 \\
\hline Soybean meal ${ }^{1}$ & 19.0 & 14.0 \\
\hline Fish oil $^{1}$ & 4.0 & 2.8 \\
\hline Soy lecithine ${ }^{1}$ & 2.0 & 3.5 \\
\hline Vitamin premix ${ }^{2, a}$ & 1.8 & 0.3 \\
\hline Mineral premix ${ }^{3, b}$ & 1.7 & 0.15 \\
\hline Vitamin E (D-alpha-tocopherol 50\%) & & 0.03 \\
\hline Vitamin $C^{4, c}$ & 0.09 & 0.06 \\
\hline Antioxidant ${ }^{5}$ & 0.004 & 0.02 \\
\hline Sodium alginate ${ }^{6}$ & 2.0 & $1^{*}$ \\
\hline Chromic oxide & 1.0 & $1^{*}$ \\
\hline
\end{tabular}

E1 = Experimental diet 1; E2 = Experimental diet 2; ' $\mathrm{ODONAJI,} \mathrm{Distribuidora} \mathrm{de} \mathrm{Alimentos} \mathrm{Naturales} \mathrm{y} \mathrm{Nutricionales,} \mathrm{La} \mathrm{Paz,} \mathrm{B.C.S.,}$ Mexico. ${ }^{2}$ Vitamin premix (g $/ \mathrm{kg}$ ): A acetate, 15; D3, 7.5; E, 4; K3, 2.0; choline chloride, $400 \mathrm{mg}$; thiamin, 150; riboflavin,100; pyridoxine, 50; pantothenic acid,100; niacin, 300; biotin, 1; inositol, 500; folic acid, 20; cyanocobalamin, 0.1 . ${ }^{\text {a }}$ Vitamin mixture composition: retinol, $4000 \mathrm{IU} / \mathrm{g}$; thiamin, 24; riboflavin, 16; DL Ca pantotenate, 30; pyridoxine, 30; cyanocobalamin, $80 \mathrm{mg} / \mathrm{kg}$; ascorbic acid, 60; menadione, 16; cholecalciferol, $3200 \mathrm{IU} / \mathrm{g}$; tocopherol, 60; biotin, $400 \mathrm{mg} / \mathrm{kg}$; niacin, $20 \mathrm{mg} / \mathrm{kg}$; folic acid, $4 .{ }^{3} \mathrm{Mineral} \mathrm{premix}$ (g/kg of diet). BASF, D.F., Mexico; ${ }^{b} \mathrm{Co}, 2 ; \mathrm{Mn}, 16 ; \mathrm{Zn}, 40 ; \mathrm{Cu}, 20 ; \mathrm{Fe}, 1 \mathrm{mg} / \mathrm{kg} ; \mathrm{Se}, 100 \mathrm{mg} / \mathrm{kg}$; I, $2{ }^{4}$ Butylated hydroxytoluen, Costa Mesa, CA, USA; ' Vitamin C. BASF, Mexico. Antioxidant: Dresquin 66, Dressen SA de CV, D.F., Mexico.

above (E1 and E2) and tested at each salinity level (5, 35 , and $50 \mathrm{ppt})$. The feeding rate during the culture period was set at $5 \%$ total shrimp biomass in each experimental tank. Shrimp were fed twice daily (09:00 and 17:00 h). Unconsumed feed, exuviates, overnight feces, and dead shrimp were removed daily $(08: 00 \mathrm{~h})$ by siphoning with a plastic hose $(0.5 \mathrm{~cm}$ in diameter). Feces were collected twice daily (10:30 and $18: 30 \mathrm{~h}$ ), by gently siphoning fecal strands with a Pasteur pipette. Feces were gently rinsed with distilled water, transferred to $30-\mathrm{mL}$ conic tubes, and frozen at $-20{ }^{\circ} \mathrm{C}$. Pooled samples of frozen fecal matter from each day and tank were freeze-dried, ground, thoroughly mixed, and kept frozen at $-80{ }^{\circ} \mathrm{C}$ until further analysis.

The trial was conducted in an experimental unit consisting of 60 -L rectangular indoor plastic tanks $(58 \times 48 \times 25 \mathrm{~cm})$, filled with filtered $(5-\mu \mathrm{m})$, and UV sterilized marine water, under constant aeration. Each tank was stocked with 10 juvenile shrimp (mean: 4.0 $\pm 0.5 \mathrm{~g}$ ). To reach a salinity of $5 \mathrm{ppt}$, fresh water was gradually added to seawater, reducing salinity at a rate of $\sim 5$ ppt per day, as recommended by JAIMECEBALLOS et al. (2008). Seawater was used for the second set of trials, adjusting salinity as needed. For high salinity trials (50 ppt), a 1100-L tank was filled with seawater and iodide-free salt was added until the desired salinity was obtained. Salinity was recorded using a refractometer (Model RF20, Extech Instruments, Waltham, MA, USA) in 15-20 min intervals until $50 \mathrm{ppt}$ was reached.

Water temperature and $\mathrm{O}_{2}$ concentration were measured daily using a multi-parameter probe (Model 55, YSI, Yellow Springs, OH, USA), while nitrites and nitrates were recorded once a week using a portable spectrophotometer (Hach DREL 2800, Loveland, CO, USA). Alkalinity was determined volumetrically with phenolphthalein and bromocresol, using sulfuric acid in a $25-\mathrm{mL}$ digital burette with precision of $\pm 30 \mu \mathrm{L}$. Total phosphorus, orthophosphates and ammonium ion content were measured according to MURPHY \& RILEY (1962) \& SOLÓRZANO (1969), with a spectrophotometer (Hach DR/2000, Loveland, CO, USA). The photoperiod was kept to a 12:12 h light:dark cycle.

\section{Diet hydrostability analysis}

Diet hydrostability was measured by determining the amount of retained dry matter after water immersion according to OBALDO et al. (2002) and GUCIC et al. (2013). Two grams of feed was placed in 250-mL Erlenmeyer flasks with 200 $\mathrm{mL}$ water at 5,35 , and 50 ppt salinity for one hour. During this time, the flasks were gently swirled on a 
platform shaker at $100 \mathrm{rpm}$ at room temperature $(\sim 27$ $\left.{ }^{\circ} \mathrm{C}\right)$ to disperse and submerge feed pellets.

\section{Chemical analysis of ingredients and diets}

Diet samples (Table 2) were finely ground and sieved, then analyzed in triplicates. The following variables were analyzed according to the corresponding method (AOAC, 2005): dry matter (weight difference, dried in an oven at $105{ }^{\circ} \mathrm{C}$ for $24 \mathrm{~h})$; crude protein $(\% \mathrm{~N} \times 6.25)$ using the Kjeldahl nitrogen method (Foss, Hillerød, DK); crude lipid using the ether-extraction method (Soxtec Avanti, Höganäs, SWE); crude fiber using the method of Weende and van Soest (Fibertec, Foss, Hillerød, DK); ash and nitrogen-free extract with standard methods (AOAC, 2005); and gross energy using an adiabatic calorimeter (Parr Instrument, Moline, IL, USA).

Diet and fecal samples ( 1.9g wet feces) were deposited on Whatman No. 3 filter paper and analyzed for dry matter (DMR) calculated as:

DMR $(\%)=(\mathrm{dw}$ residual feed after immersion $/ \mathrm{dw}$ initial feed $) \times 100$.

Protein was determined using the micro Kjeldahl method (Tecator, Höganäs, SWE). The concentration of chromic oxide $\left(\mathrm{Cr}_{2} \mathrm{O}_{3}\right)$ was determined by digesting organic matter with nitric acid and oxidizing $\mathrm{Cr}_{2} \mathrm{O}_{3}$ to $\mathrm{Cr}_{2} \mathrm{O}_{7}$ with perchloric acid, followed by a colorimetric analysis of the dichromate ion with diphenylcarbazide (FURUKAWA \& TSUKAHARA, 1966).

\section{In vivo digestibility}

Apparent digestibility coefficients (ADC) for dry matter, protein, and energy were determined as recommended by CHO \& SLINGER (1979), using the following equations:

ADC of nutrients $(\%)=100-100[(\%$ $\mathrm{Cr}_{2} \mathrm{O}_{3}$ in feed $) /\left(\% \mathrm{Cr}_{2} \mathrm{O}_{3}\right.$ in feces $) \times(\%$ nutrient in feces $) /(\%$ nutrient in feed $)$ ]

ADC of energy $(\%)=($ digestible energy $(\mathrm{kJ} / \mathrm{g}) /$ gross energy $(\mathrm{kJ} / \mathrm{g}) \times 100$.

\section{Statistical analysis}

Kolmogorov-Smirnov and Bartlett tests were applied to the data to determine normality and homogeneity of variance, respectively. The statistical significance level was set at $\mathrm{P}<0.05$. A two-way analysis of variance (ANOVA) was used to determine significant difference between groups (3 salinities; 8 diets). In the presence of significant interactions, one-way analysis of variance (ANOVA) was used. Tukey's multiple-range test was used to identify significant differences among digestibility coefficients. A principal component analysis (PCA) using a covariance matrix was performed to explore differences between treatments as a function of diet and salinity interaction (ZAR, 1999). Data were analyzed using the software Statistica 11.0 (StatSoft, Tulsa, OK, USA). Data expressed in percentages were transformed using the square root of the arcsine before statistical analyses.

\section{RESULTS}

Water quality parameters were well within safe ranges for shrimp rearing. The measured ranges obtained for water temperature $\left(28.5{ }^{\circ} \mathrm{C}-29.1{ }^{\circ} \mathrm{C}\right)$, dissolved oxygen $\left(5.1-5.4 \mathrm{mg} \mathrm{L}^{-1}\right)$, nitrites $(<0.10$

Table 2 - Proximate analysis (g/100 g in dry matter) of experimental and commercial diets for juvenile Litopenaeus vanamei shrimp.

\begin{tabular}{|c|c|c|c|c|c|c|c|c|}
\hline & E1 & E2 & D1 & D2 & D3 & D4 & D5 & D6 \\
\hline Dry matter & $93.0 \pm 0.23^{\mathrm{a}}$ & $93.6 \pm 0.17^{\mathrm{c}}$ & $92.4 \pm 0.09^{d}$ & $91.3 \pm 0.09^{\mathrm{e}}$ & $92.3 \pm 0.07^{\mathrm{d}}$ & $91.7 \pm 0.23^{\mathrm{e}}$ & $93.3 \pm 0.04^{\mathrm{a}}$ & $93.0 \pm 0.22^{\mathrm{a}}$ \\
\hline $\begin{array}{l}\text { Crude protein } \\
(\mathrm{N} \times 6.25)\end{array}$ & $33.5 \pm 0.27^{g}$ & $33.4 \pm 0.45^{\mathrm{g}}$ & $37.9 \pm 0.15^{\mathrm{c}}$ & $38.3 \pm 0.25^{b}$ & $39.0 \pm 0.08^{\mathrm{a}}$ & $34.5 \pm 0.08^{f}$ & $35.6 \pm 0.30^{\mathrm{e}}$ & $37.4 \pm 0.0 .5^{\mathrm{d}}$ \\
\hline Ether extract & $7.0 \pm 0.1^{b, c}$ & $7.0 \pm 2.0^{\mathrm{b}, \mathrm{c}}$ & $8.2 \pm 0.02^{\mathrm{a}, \mathrm{b}}$ & $9.4 \pm 1.3^{\mathrm{a}}$ & $9.3 \pm 0.02^{\mathrm{a}}$ & $5.9 \pm 0.78^{c}$ & $9.5 \pm 0.03^{\mathrm{a}}$ & $7.2 \pm 2.0^{\mathrm{b}, \mathrm{c}}$ \\
\hline Ash & $8.7 \pm 0.03^{h}$ & $11.5 \pm 0.04^{\mathrm{d}}$ & $11.2 \pm 0.07^{\mathrm{e}}$ & $14.4 \pm 0.04^{\mathrm{a}}$ & $12.0 \pm 0.10^{\mathrm{c}}$ & $9.7 \pm 0.04^{\mathrm{g}}$ & $12.2 \pm 0.03^{\mathrm{b}}$ & $10.3 \pm 0.03^{\mathrm{f}}$ \\
\hline Crude fiber & $3.0 \pm 0.26^{\mathrm{a}}$ & $1.5 \pm 0.00^{\mathrm{b}}$ & $1.3 \pm 0.00^{\mathrm{b}, \mathrm{c}}$ & $1.4 \pm 0.00^{\mathrm{b}}$ & $0.6 \pm 0.61^{\mathrm{d}}$ & $1.0 \pm 0.06^{\mathrm{c}, \mathrm{d}}$ & $0.9 \pm 0.03^{\mathrm{d}}$ & $1.5 \pm 0.22^{b}$ \\
\hline $\begin{array}{l}\text { Nitrogen-free } \\
\text { extract }\end{array}$ & $49.2 \pm 0.26^{\mathrm{a}}$ & $45.0 \pm 2.26^{\mathrm{b}}$ & $41.3 \pm 0.24^{\mathrm{cd}}$ & $36.4 \pm 1.58^{\mathrm{f}}$ & $39.2 \pm 0.79^{\text {ef }}$ & $49.0 \pm 0.72^{\mathrm{a}}$ & $41.8 \pm 0.39^{\mathrm{c}, \mathrm{d}}$ & $43.6 \pm 0.75^{\mathrm{b}, \mathrm{c}}$ \\
\hline $\begin{array}{l}\text { Gross energy } \\
(\mathrm{kJ} / \mathrm{g})\end{array}$ & $18.3 \pm 0.2^{b}$ & $18.2 \pm 0.1^{\mathrm{c}}$ & $18.2 \pm 0.1^{\mathrm{c}}$ & $17.9 \pm 0.0^{\mathrm{d}}$ & $18.2 \pm 0.0^{\mathrm{cd}}$ & $17.8 \pm 0.1^{\mathrm{e}}$ & $18.2 \pm 0.1^{\mathrm{c}}$ & $18.4 \pm 0.0^{\mathrm{a}}$ \\
\hline
\end{tabular}

${ }^{1}$ Values are means of three determinations \pm standard deviation (SD). Values within the same row with different superscripts are significantly different $(\mathrm{P}<0.05)$. E1 = Experimental diet 1 ; E2 = Experimental diet 2; D1 = Commercial diet 1; D2 = Commercial diet 2; D3 = Commercial diet 3; D4 = Commercial diet 4; D5 = Commercial diet 5; D6 = Commercial diet 6. 
$\left.0.26 \mu \mathrm{m} \mathrm{L}^{-1}\right)$, nitrate $\left(4.00-12.8 \mu \mathrm{m} \mathrm{L}^{-1}\right)$, alkalinity (130.2-141.7 mg $\mathrm{CaCO}_{3} \mathrm{~L}^{-1}$ ), orthophosphates $\left(0.248-0.582 \mu \mathrm{M} \mathrm{L}^{-1}\right)$, and phosphorus $(0.233-0.680$ $\mu \mathrm{M} \mathrm{L}^{-1}$ ) were not significantly different between treatments (Table 3).

Results of stability in water for all diets and ADC of dry matter, proteins and energy are shown in table 4. The statistical analysis demonstrated that the diet factor had an important effect on stability in water of pellets. The most significantly stable pellets $(\mathrm{P}<0.05)$ were those obtained for the diets $\mathrm{E} 1, \mathrm{E} 2$, $\mathrm{D} 4$, and D6.

The diets E2 and D4 used in shrimp feed were significantly better $(\mathrm{P}<0.05)$ in coefficient of digestibility of dry matter. With respect to protein digestibility the highest values $(\mathrm{P}<0.05)$ were observed for the diets E2 and D4. Energy digestibility was significantly $(\mathrm{P}<0.05)$ affected by the different diets. They were significantly higher in dietary treatments D2, D3, D4, D5, and E2.

The ANOVA analysis demonstrated that the salinity factor had an important effect on stability in water and apparent digestibility of diets, which were significantly better $(\mathrm{P}<0.05)$ at a salinity of $35 \mathrm{ppt}$ for energy digestibility, 35 and $50 \mathrm{ppt}$ for hydrostability, 35 and 5 ppt for digestibility of dry matter and protein.

In this investigation, the interaction of diet and salinity factors showed a total of 24 interactions (independent variables). ANOVA was applied, and significant differences $(P<0.05)$ were found in response variables of hydrostability in pellets, digestibility of dry matter, proteins and energy on diet. Hydrostability in pellets varied from 86.8 to $99.9 \%$; dry matter digestibility varied from $49.1 \%$ to $64.1 \%$; protein digestibility showed greater variations at all salinities $(56.9 \%-85.8 \%)$; and energy digestibility ranged from 70.1 to $86.4 \%$. However, the Principal Component Analysis (PCA) was applied and significant differences $(\mathrm{P}<0.05)$ were reported between the 24 interactions.

The PCA using a covariance matrix to explore differences in the response of hydrostability in pellets, digestibility of dry matter, proteins and energy on diet from juvenile shrimps to diet- salinity interaction is shown in figure 1 . The plot PC1 vs. PC2 (using their multipliers as a variable) showed a clear pattern. PC1 (48.3\%) and PC2 (24.9\%) jointly accounted for $73.2 \%$ of the differences in hydrostability, digestibility of dry matter, protein, and energy responses. For PC1, the main differences were observed in dry matter, protein, and energy. For PC2, the main difference was the hydrostability.

The diet - salinity ratio plot suggested that the formulated diet E2 at $35 \mathrm{ppt}$ (Interaction - J) was optimal as shrimp feed, given its position at the top of the plot to the right (highly positive for PC1 and PC2). Conversely, the ratio for E1 and salinity at 5 ppt was collected (Interaction - A) around the zero point at PC1 but still positive in the upper part of the plot to the right (highly positive for both $\mathrm{PC} 1$ and PC2). This result was not the case for the other diets; for instance, the diet - salinity ratio of D6 at $50 \mathrm{ppt}$ (Interaction -X) was more negative in PC1 than PC2.

\section{DISCUSSION}

All tanks were maintained according to recommended aquaculture practices (BUCKLE et al., 2006; CRUZ-SUÁREZ et al., 2009; ABDELRAHMAN et al., 2019; ALVES et al., 2019; CHEN et al., 2019), ensuring that environmental conditions did not influence our results. Good acceptance for all commercial and formulated diets was observed throughout the trial.

The findings in this study indicated that salinity level has a significant effect on shrimp's digestibility of dry matter, protein, and energy,

Table 3 - Water quality parameters (mean \pm standard deviation $[\mathrm{SD}]$ ) recorded during the trials for juvenile Litopenaeus vannamei shrimp.

\begin{tabular}{lccccccc}
\hline Salinity & Temp. & $\mathrm{O}_{2}$ & Nitrites & Nitrates & Orthophosphates & Phosphorus & Alkalinity \\
\hline $\mathrm{Ppt}$ & ${ }^{\circ} \mathrm{C}$ & $\mathrm{mg} \mathrm{L}^{-1}$ & $\mu \mathrm{M} \mathrm{L}^{-1}$ & $\mu \mathrm{M} \mathrm{L}^{-1}$ & $\mu \mathrm{M} \mathrm{L}^{-1}$ & $\mu \mathrm{M} \mathrm{L}^{-1}$ & $\mathrm{mg} \mathrm{L}^{-1}$ \\
5 & $27.5 \pm 0.9$ & $5.1 \pm 0.7$ & 0.261 & 4.00 & 0.248 & 0.233 & $\mathrm{CaCO}_{3}$ \\
35 & $27.6 \pm 0.6$ & $5.4 \pm 0.4$ & 0.145 & 12.8 & 0.582 & 0.680 & 137.9 \\
50 & $27.4 \pm 0.5$ & $5.0 \pm 0.5$ & $<0.100$ & 11.5 & 0.321 & 0.604 & 138.8 \\
\hline
\end{tabular}

$\mu \mathrm{M}=$ Micromoles. 
Table 4 - Hydrostability of dry matter, apparent digestibility coefficients of dry matter, protein, and energy for two experimental (E1 and E2) and six commercial (D1, D2, D3, D4, D5 and D6) diet formulations for juvenile Litopenaeus vannamei shrimp cultivated at three different salinity levels $(5,35$, and $50 \mathrm{ppt})$.

\begin{tabular}{|c|c|c|c|c|c|}
\hline \multicolumn{2}{|c|}{---------------'Interaction------------- } & \multirow{2}{*}{$\begin{array}{l}\text { Hydrostability } \\
\text { Dry matter (\%) }\end{array}$} & \multicolumn{3}{|c|}{ - } \\
\hline Salinity (ppt) & Diet & & Dry matter & Protein & Energy \\
\hline \multirow{9}{*}{ (5) } & E1 & $94.8 \pm 0.3 \mathrm{ab}$ & $69.6 \pm 1.2 \mathrm{a}$ & $78.6 \pm 1.6 \mathrm{bc}$ & $72.0 \pm 0.1 \mathrm{~d}$ \\
\hline & E2 & $91.5 \pm 0.3 \mathrm{~b}$ & $69.0 \pm 1.2 \mathrm{a}$ & $79.8 \pm 0.8 \mathrm{~b}$ & $77.6 \pm 5.0 \mathrm{~b}$ \\
\hline & D1 & $89.5 \pm 0.4 \mathrm{bc}$ & $58.1 \pm 1.1 \mathrm{~b}$ & $56.9 \pm 1.4 \mathrm{f}$ & $72.3 \pm 0.5 \mathrm{~cd}$ \\
\hline & D2 & $86.8 \pm 1.5 \mathrm{~d}$ & $65.1 \pm 2.0 \mathrm{~b}$ & $83.3 \pm 2.0 \mathrm{a}$ & $77.9 \pm 5.8 \mathrm{~b}$ \\
\hline & D3 & $88.4 \pm 1.0 \mathrm{~cd}$ & $67.3 \pm 2.7 \mathrm{a}$ & $76.3 \pm 3.3 \mathrm{~cd}$ & $83.1 \pm 1.6 \mathrm{a}$ \\
\hline & D4 & $93.5 \pm 0.8 \mathrm{~b}$ & $69.4 \pm 1.7 \mathrm{a}$ & $72.6 \pm 1.8 \mathrm{e}$ & $83.5 \pm 1.6 \mathrm{a}$ \\
\hline & D5 & $88.0 \pm 0.8 \mathrm{~cd}$ & $52.1 \pm 4.4 \mathrm{c}$ & $57.7 \pm 2.9 \mathrm{f}$ & $78.6 \pm 2.3 \mathrm{~b}$ \\
\hline & D6 & $91.4 \pm 0.7 \mathrm{bc}$ & $62.2 \pm 0.4 \mathrm{~b}$ & $74.1 \pm 0.4 \mathrm{de}$ & $73.4 \pm 3.0 \mathrm{c}$ \\
\hline & E1 & $99.6 \pm 0.6 \mathrm{a}$ & $64.2 \pm 3.3 \mathrm{~b}$ & $77.8 \pm 3.3 \mathrm{~cd}$ & $77.8 \pm 1.0 \mathrm{c}$ \\
\hline \multirow{7}{*}{35} & E2 & $94.7 \pm 2.7 \mathrm{ab}$ & $70.0 \pm 1.1 \mathrm{a}$ & $83.1 \pm 1.1 \mathrm{a}$ & $80.1 \pm 2.4 \mathrm{ab}$ \\
\hline & D1 & $97.5 \pm 2.6 \mathrm{ab}$ & $61.8 \pm 2.2 \mathrm{~b}$ & $71.2 \pm 2.4 \mathrm{e}$ & $76.5 \pm 2.1 \mathrm{c}$ \\
\hline & $\mathrm{D} 2$ & $96.7 \pm 2.3 \mathrm{ab}$ & $63.8 \pm 3.1 \mathrm{~b}$ & $85.8 \pm 1.7 \mathrm{a}$ & $78.0 \pm 1.3 \mathrm{c}$ \\
\hline & D3 & $96.5 \pm 1.7 \mathrm{ab}$ & $68.6 \pm 1.2 \mathrm{a}$ & $80.3 \pm 3.6 \mathrm{bc}$ & $79.9 \pm 1.0 \mathrm{bc}$ \\
\hline & D4 & $99.0 \pm 1.5 \mathrm{a}$ & $71.9 \pm 1.8 \mathrm{a}$ & $77.7 \pm 2.6 \mathrm{~cd}$ & $86.3 \pm 2.3 \mathrm{a}$ \\
\hline & D5 & $92.0 \pm 2.8 \mathrm{~b}$ & $59.4 \pm 1.0 \mathrm{~b}$ & $70.3 \pm 1.1 \mathrm{e}$ & $80.8 \pm 2.2 \mathrm{ab}$ \\
\hline & D6 & $96.4 \pm 3.4 \mathrm{ab}$ & $61.6 \pm 3.4 \mathrm{~b}$ & $76.4 \pm 3.7 \mathrm{~d}$ & $78.6 \pm 2.4 \mathrm{c}$ \\
\hline \multirow{8}{*}{50} & E1 & $99.9 \pm 0.1 \mathrm{a}$ & $53.9 \pm 3.6 \mathrm{bc}$ & $69.5 \pm 3.2 \mathrm{cde}$ & $80.5 \pm 1.7 \mathrm{ab}$ \\
\hline & E2 & $99.0 \pm 1.5 \mathrm{a}$ & $64.1 \pm 1.8 \mathrm{~b}$ & $78.9 \pm 2.2 \mathrm{bc}$ & $73.2 \pm 3.7 \mathrm{c}$ \\
\hline & D1 & $97.7 \pm 0.6 \mathrm{ab}$ & $59.0 \pm 2.4 \mathrm{~b}$ & $70.2 \pm 1.4 \mathrm{cde}$ & $79.9 \pm 0.9 \mathrm{~b}$ \\
\hline & $\mathrm{D} 2$ & $96.8 \pm 0.5 \mathrm{ab}$ & $59.4 \pm 2.4 \mathrm{~b}$ & $83.8 \pm 2.0 \mathrm{a}$ & $83.4 \pm 0.4 \mathrm{a}$ \\
\hline & D3 & $97.7 \pm 1.1 \mathrm{ab}$ & $60.2 \pm 2.8 \mathrm{~b}$ & $74.4 \pm 3.6 \mathrm{bc}$ & $79.3 \pm 4.7 \mathrm{~b}$ \\
\hline & D4 & $99.1 \pm 0.8 \mathrm{a}$ & $63.8 \pm 2.6 \mathrm{~b}$ & $72.0 \pm 2.7 \mathrm{~cd}$ & $78.6 \pm 3.4 \mathrm{bc}$ \\
\hline & D5 & $93.2 \pm 2.1 \mathrm{~b}$ & $49.1 \pm 1.0 \mathrm{c}$ & $63.8 \pm 0.6 \mathrm{e}$ & $73.5 \pm 0.9 \mathrm{c}$ \\
\hline & D6 & $99.0 \pm 1.8 \mathrm{a}$ & $51.3 \pm 2.4 \mathrm{c}$ & $67.1 \pm 1.9 \mathrm{de}$ & $70.0 \pm 1.9 \mathrm{~d}$ \\
\hline \multirow{2}{*}{\multicolumn{2}{|c|}{ F1 }} & - & t factor--------. & & 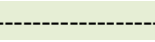 \\
\hline & & $98.1 \pm 0.3 \mathrm{a}$ & $62.6 \pm 2.8 \mathrm{bc}$ & $62.6 \pm 2.8 b c$ & $76.8 \pm 0.9 b$ \\
\hline \multicolumn{2}{|l|}{ E2 } & $95.3 \pm 1.5 \mathrm{ab}$ & $67.7 \pm 1.4 \mathrm{a}$ & $67.7 \pm 1.4 \mathrm{a}$ & $77.1 \pm 3.7 \mathrm{ab}$ \\
\hline \multicolumn{2}{|l|}{ D1 } & $94.9 \pm 1.2 \mathrm{~b}$ & $59.6 \pm 1.9 \mathrm{c}$ & $59.6 \pm 1.9 \mathrm{c}$ & $76.2 \pm 1.2 b$ \\
\hline \multicolumn{2}{|l|}{ D2 } & $93.4 \pm 1.4 b$ & $62.8 \pm 2.5 b c$ & $62.8 \pm 2.5 b c$ & $79.8 \pm 2.5 \mathrm{ab}$ \\
\hline \multicolumn{2}{|l|}{ D3 } & $94.2 \pm 1.3 b$ & $65.4 \pm 2.2 \mathrm{~b}$ & $65.4 \pm 2.2 \mathrm{~b}$ & $80.8 \pm 2.4^{\mathrm{a}}$ \\
\hline \multicolumn{2}{|l|}{ D4 } & $97.2 \pm 1.0 \mathrm{a}$ & $68.4 \pm 2.0 \mathrm{a}$ & $68.4 \pm 2.0 \mathrm{a}$ & $82.8 \pm 2.4^{\mathrm{a}}$ \\
\hline \multicolumn{2}{|l|}{ D5 } & $91.1 \pm 1.9 b$ & $53.5 \pm 2.1 \mathrm{~d}$ & $53.5 \pm 2.1 \mathrm{~d}$ & $77.6 \pm 1.8 \mathrm{ab}$ \\
\hline \multicolumn{2}{|l|}{ D6 } & $95.6 \pm 2 \mathrm{ab}$ & $58.4 \pm 2.1 \mathrm{c}$ & $58.4 \pm 2.1 \mathrm{c}$ & $74.0 \pm 2.4 \mathrm{~b}$ \\
\hline \multicolumn{6}{|c|}{ pt) 1actor----- } \\
\hline \multicolumn{2}{|l|}{5} & $90.5 \pm 0.7 b$ & $64.0 \pm 1.8 \mathrm{a}$ & $64.0 \pm 1.8 \mathrm{a}$ & $77.2 \pm 2.5 b$ \\
\hline \multicolumn{2}{|l|}{35} & $96.6 \pm 2.2 \mathrm{a}$ & $65.3 \pm 2.1 \mathrm{a}$ & $65.3 \pm 2.1 \mathrm{a}$ & $79.8 \pm 1.8^{\mathrm{a}}$ \\
\hline \multicolumn{2}{|l|}{50} & $97.8 \pm 1.1 \mathrm{a}$ & $57.6 \pm 2.4 b$ & $57.6 \pm 2.4 b$ & $77.1 \pm 2.2 b$ \\
\hline \multicolumn{2}{|c|}{ Two-way ANOVA } & F & & & \\
\hline \multicolumn{2}{|c|}{ Diet (d.f. $=7)$} & 19.4 & 38.1 & 38.1 & 6.9 \\
\hline \multicolumn{2}{|c|}{ Salinity $($ d.f. $=2)$} & 32.1 & 62.6 & 62.6 & 11.1 \\
\hline \multicolumn{2}{|c|}{ Interaction (d.f. $=14)$} & 5.3 & 4.1 & 4.1 & 5.8 \\
\hline
\end{tabular}

${ }^{1}$ Values are means of three determinations \pm standard deviation (SD). Values within the same column with different superscripts are significantly different $(\mathrm{P}<0.05)$. E1 = Experimental diet 1; E2 = Experimental diet 2; D1 = Commercial diet 1; D1 = Commercial diet 2; $\mathrm{D} 1=$ Commercial diet 3; D1 = Commercial diet 4; D1 = Commercial diet 5; D1 = Commercial diet 6; d.f $=$ degrees of freedom.

concurring with previous studies (ROSAS et al., 2001; OBALDO et al. 2002, CRUZ-SUÁREZ et al., 2009). Previous research has also shown that salinity significantly influenced the metabolism of penaeid shrimps (ROSAS et al., 2001, ZHU et al., 2006). As salinity deviates from the iso-osmotic point, the osmotic balance in shrimp is modified and the organism expends more energy on osmoregulation 


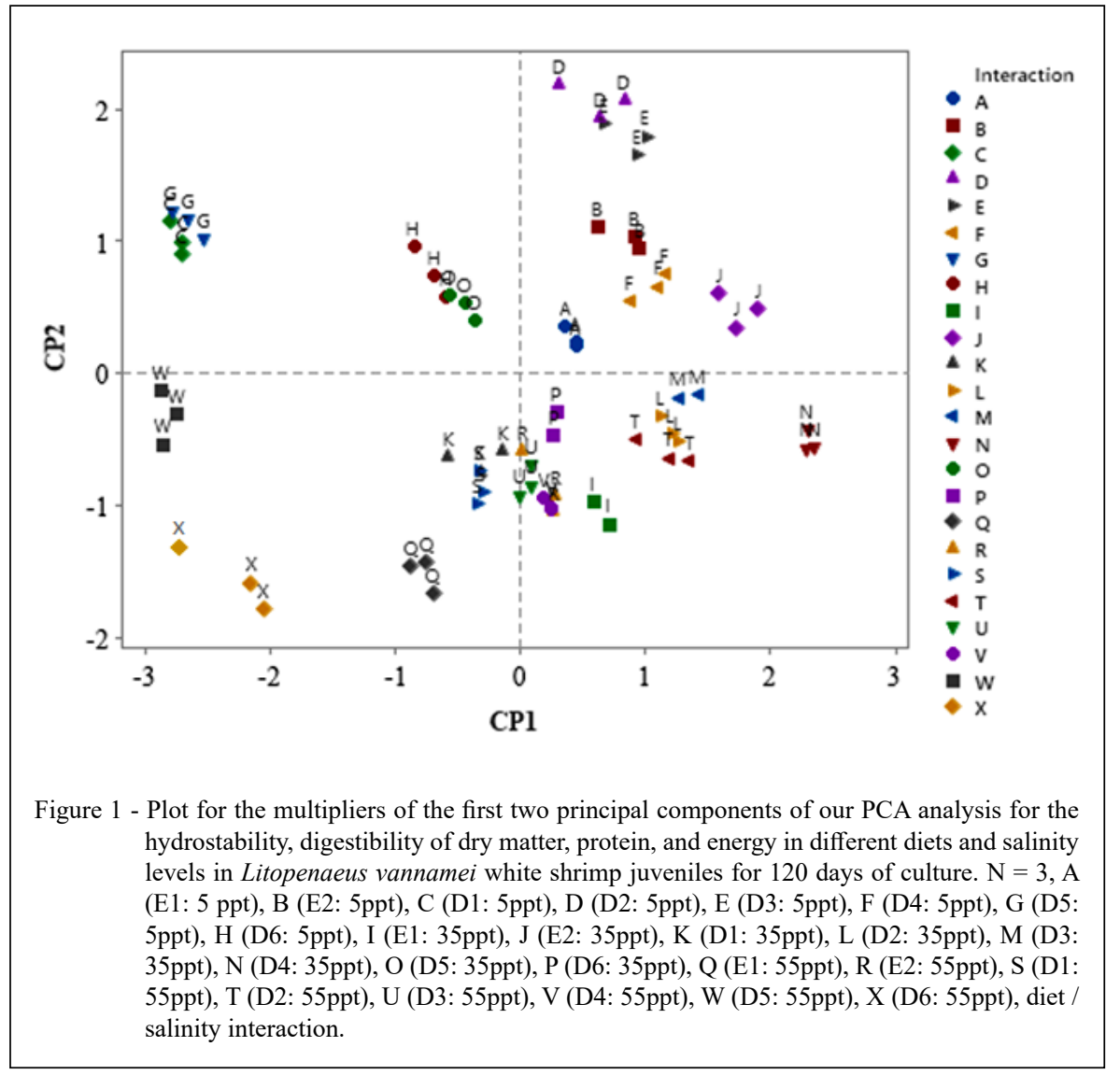

and less on growth (HURTADO et al., 2006). Shrimp are excellent osmo-regulators if ionic ratios in water are adequate (GONG et al., 2004, ROY et al., 2007). Osmoregulation is determined by the interaction between physiological requirements for water nutrients and mineral profile (DAVIS et al., 2002).

Our results also showed that salinity had a significant effect on DMR: leaching was significantly higher at low salinity levels. At the highest salinity level (50 and $35 \mathrm{ppt})$, ionic concentrations $\left(\mathrm{Cl}^{-}\right.$, $\mathrm{HCO}_{3}^{-}$, and $\mathrm{SO}_{4}^{2-}$ ) were higher than in lower salinity treatments, which delayed the rapid leaching of feed, thereby influencing the digestibility coefficient of dry matter. The observed values in this study were similar to findings by CRUZ-SUAREZ et al. (2009) at $35 \mathrm{ppt}$ salinity, but lower than those reported by XIA et al. (2010) at equal salinity. The high DMR in all diets indicated that the ingredients used for both formulation and elaboration methods were adequate.

Protein is the most critical ingredient in shrimp feed, both in terms of cost and organism's growth response. Proteins are crucial from an ecological point of view, as they are a major source of nitrogen in aquaculture ponds, which may cause hyper-nutrification. The protein APD coefficients showed differences between commercial and experimental feed: significantly higher APDs were observed at $35 \mathrm{ppt}$ than those described by CRUZ-SUÁREZ et al. (2009). Apparently, the optimal salinity for growth is associated with protein metabolism, as free amino acids are involved in the regulation and maintenance of cell volume.

Energy AED coefficients showed significant differences between experimental and commercial diets within each salinity level. The highest obtained value was for diet D4 (86.4\%) at 35 ppt interaction; although, it did not differ significantly $(\mathrm{P}>0.05)$ from diet - salinity ratio E2: 35 ppt, D5: 35 ppt, E1: 50 ppt and D2: $50 \mathrm{ppt}$, which was related to the shrimp's energy expenditure at higher salinity levels.

For all diets, the best hydrostability values were observed at higher salinities; however, the E1 diet was the most hydrostable out of all the tested diets. That being said, high hydrostability does not necessarily indicate high diet performance - on the 
contrary, it could indicate lower overall digestibility (GUCIC et al., 2013). Diet E1 had the highest hydrostability and the lowest digestibility of dry matter, protein, and energy.

When different diets based on animal and plant meals for Argentine stiletto shrimp (Artemesia longinaris) were evaluated, FERNÁNDEZGIMENEZ et al. (2009) reported percentages of digestibility of $92.15,83.83$, and $63.13 \%$ for fishmeal, meat meal and soybean meal respectively. ANAYA-ROSAS et al. (2017) reported in three macroalgae (Gracilaria vermiculophylla, Dictyota dichotoma, Ulva lactuca) digestibility percentages for dry matter and protein ranging from 41.6 to $72.1 \%$, and 56.0 to $82.19 \%$, respectively. Additionally, JANNATHULLA et al. (2017) reported that the ADC of dry matter and protein ranged from 58.74 to $74.31 \%$ and 62.43 to $80.25 \%$, respectively, in soybean diets for L. vannamei. GUCIC et al. (2013) evaluated the apparent digestibility of carbohydrates and lipids in white shrimp feeds at different salinities $(5,35$, and $50 \mathrm{ppt})$ and reported better stability $(>86 \%)$ for diets at $5 \mathrm{ppt}$, with the lowest lipid digestibility at 50 ppt (74\%) while carbohydrate digestibility was greater at 5 ppt (90\%). They suggested that the high hydrostability observed at low salinity levels did not necessarily imply a better production response but could induce a lower digestibility.

In this study, diets with greater hydrostability showed a lower protein and dry material digestibility; although, this result could also be explained by the chemical composition of the diet, as well as the digestive characteristics of the species and environmental conditions in which the study was conducted.

In this study, the interaction between salinity and diet was observed to have a significant effect on digestibility of dry matter, protein, and energy in shrimp, suggesting the possibility of manipulating dry matter, protein, and energy in shrimp feeds at different culture salinities to achieve a desired response of farmed shrimp. However, further research is needed to analyze the digestive enzyme activity and hepatopancreas histology of reared shrimp, enabling a better understanding of the processes and mechanisms involved. Furthermore, researchers should also investigate the influence of different management practices on shrimp aquaculture production (both in terms of output quantity and quality).

\section{CONCLUSION}

The results of this study allowed us to conclude that diet formulation and water salinity has a significant influence on hydrostability and digestibility of shrimp feed. The PCA suggested that a diet -salinity ratio between formulated diet E2 and salinity at $35 \mathrm{ppm}$ promotes hydrostability, digestibility and proper nutrient use in white shrimp juveniles, which could be set as recommendable for further studies on feed formulation for the species.

\section{ACKNOWLEDGMENTS}

The authors thank S. de La Paz, S. Rocha, D. Rondero, and E. Goytortúa, for their hard work and dedication to complete this study; to D. Fischer for editorial services. Shrimp were obtained from Granjas Marinas de Sinaloa S.A. de C.V. Funding was provided by Secretaria de Agricultura, Ganadería, Desarrollo Rural, Pesca y Alimentación y Consejo Nacional de Ciencia y Tecnología (SAGARPA-CONACYT) Project 2003-C02149 and CONACYT-FC2016/2930.

\section{DECLARATION OF CONFLICT OF INTEREST}

The authors declare no conflict of interest. Funding sponsors had no role in the design of the study; collection, analyses or interpretation of data; writing of the manuscript and in the decision to publish the results.

\section{AUTHORS' CONTRIBUTIONS}

All authors contributed equally for the conception and writing of the manuscript. All authors critically revised the manuscript and approved of the final.

\section{REFERENCES}

ABDELRAHMAN, H. A. et al. Influence of variation in ater temperature on survival, growth and yield of Pacific white shrimp Litopenaeus vannamei in inland ponds for lowsalinity culture. Aquaculture Research, v.50, n.2, p.658-672, 2019. Available from: <https://doi.org/10.1111/are.13943>. Accessed: May, 10, 2019. doi: 10.1111/are.13943.

AKBARZADEH, A. et al. Utilization of date seed meal in the diet of Pacific white shrimp (Penaeus vannamei): growth performance, body and fatty acid composition, biochemical parameters, and tolerance of salinity stress. Aquaculture International, v.27, n.3, p.647-661, 2019. Available from: <https://doi.org/10.1007/ s10499-019-00352-y>. Accessed: May, 10, 2019. doi: 10.1007/ s10499-019-00352-y.

AKIYAMA, D. M. et al. Penaeid shrimp nutrition for the commercial feed industry, revised. In: Akiyama, D.M.; Tan, R.K.H. (eds). Proceedings of the Aquaculture Feed Processing and Nutrition Workshop, Thailand and Indonesia. September 19-25, American Soybean Association, Singapore. 1991. p.80-98.

ALVES N. I. et al., Acute toxicity of nitrate in Litopenaeus vannamei juveniles at low salinity levels Toxicidade aguda do nitrato em juvenis de Litopenaeus vannamei em baixa salinidade. Ciência Rural, Santa Maria, v.49, n.1, p.1-9, 2019. Available from: 
$<$ http://dx.doi.org/10.1590/0103-8478cr20180439>. Accessed: May, 10, 2019. doi: 10.1590/0103-8478cr20180439.

AMIRKOLAIE, A. K. Reduction in the environmental impact of waste discharged by fish farmsthrough feed and feeding. Reviews in Aquaculture, v.3, n.1, p.19-26, 2011. Available from: <https:// doi.org/10.1111/j.1753-5131.2010.01040.x>. Accessed: May, 10, 2019. doi: $10.1111 /$ j.1753-5131.2010.01040.x.

ANAYA-ROSAS, R. E. et al. Antioxidant activity and apparent digestibility of amino acids of three macroalgae meals in the diets of Pacific white shrimp (Litopenaeus vannamei). Latin American Journal of Aquatic Research, v.45, n.5, p.970-978, 2017. Available from: <http://dx.doi.org/10.3856/vol45-issue5-fulltext-12>. Accessed: May, 10, 2019. doi: 10.3856/vol45-issue5-fulltext-12.

AOAC. Official methods of analysis. 16th ed. Association of Official Analytical Chemists, Gaithersburg, Maryland, 2005.

BÜCKLE, L. F. Osmoregulatory capacity of the shrimp Litopenaeus vannamei at different temperatures and salinities, and optimal culture environment. Revista de Biología Tropical, v.54 n.3, p.745-753, 2006. Available from: <https://revistas.ucr.ac.cr/ index.php/rbt/article/view/12773>. Accessed: May, 10, 2019. doi: 10.15517/RBT.V54I3.12773.

CAMPAÑA-TORRES, A. et al. Carbohydrate and lipid digestibility of animal and vegetal ingredients and diets for juvenile Australian redclaw crayfish, Cherax quadricarinatus (Von Martens). Aquaculture Nutrition, v.12, n.2, p.103-109, 2006. Available from: $\quad<$ https://doi.org/10.1111/j.1365-2095.2006.00388.x $>$. Accessed: May, 10, 2019. doi: 10.1111/j.1365-2095.2006.00388.x.

CHATVIJITKUL, S. et al. Pollution potential indicators for feed-based fish and shrimp culture. Aquaculture, v.477, p.43-49, 2017. Available from: <https://doi.org/10.1016/j. aquaculture.2017.04.034>. Accessed: May, 31, 2020. doi: 10.1016/j.aquaculture.2017.04.034

CHEN, K. et al. Growth and metabolomic responses of Pacific white shrimp (Litopenaeus vannamei) to different dietary fatty acid sources and salinity levels. Aquaculture, v.499, p.329-340, 2019. Available from: <https://doi.org/10.1016/j. aquaculture.2018.09.056>. Accessed: May, 10, 2019. doi: 10.1016/j.aquaculture.2018.09.056

CHO, C.; SLINGER, S. J. Apparent digestibility measurement in feedstuffs for rainbow trout. In: HALVER, J.E.; TIEWS, K. (Eds). Proceedings of the World Symposium on Finfish Nutrition and Fish Feed Technology. Hamburg, Germany, 1979. p.241-247.

CRUZ-SUÁREZ, L. E. et al. Apparent dry matter, energy, protein and aminoacid digestibility of tour soybean ingredients in white shrimp Litopenaeus vannamei juveniles. Aquaculture, v.292, p.87-94, 2009. Available from: <http://doi.10.1016/j.aquaculture.2009.03.026>. Accessed: May, 10, 2019. doi: 10.1016/j.aquaculture.2009.03.026

DAVIS, D. A.; ARNOLD, C. R. Evaluation of five carbohydrate sources for Litopenaeus vannamei. Aquaculture, v.114, p.285-292, 2002. Available from: <https://doi.10.1016/00448486(93)90303-g>. Accessed: May, 10, 2019. doi: 10.1016/00448486(93)90303-g.

FERNÁNDEZ-GIMENEZ, A. V.et al. In vivo and in vitro protein digestibility of formulated feeds for Artemesia longinaris,
(Crustacea, Penaeidae). Brazilian Archives of Biology and Technology. v.52, n.2, p.1379-1386, 2009. Available from: <http:// dx.doi.org/10.1590/S1516-89132009000600009>. Accessed: May, 10, 2019. doi: 10.1590/S1516-89132009000600009.

FURUKAWA, A.; TSUKAHARA, H. On the acid digestion method for the determination of chromic oxide as an index in the study of digestibility of fish feed. Bulletin of the Japanese Society of Scientific Fisheries, v.32, p.502-506, 1966. Available from: <https://doi.org/10.2331/suisan.32.502>. Accessed: May, 10, 2019. doi: 10.2331/suisan.32.502.

GONG, H. et al. A dietary modification approach to improve the osmoregulatory capacity of Litopenaeus vannamei culture in the Arizona desert. Aquaculture Nutrition, v.10, n.4, p.227-236, 2004. Available from: <https://doi.org/10.1111 /j.1365-2095.2004.00294.x>. Accessed: May, 10, 2019. doi: 10.1111/j.1365-2095.2004.00294.x.

GUCIC, M. et al. Apparent carbohydrate and lipid digestibility of feeds for whiteleg shrimp, Litopenaeus vannamei (Decapoda: Penaeidae), cultivated at different salinities. Revista de Biología Tropical. v.61, p.1201-1213, 2013. Available from: $<$ https://www.ncbi.nlm.nih.gov/pubmed/24027918>. Accessed: May, 10, 2019

HOSSEIN H. S. et al. Modulation of nutrient digestibility and digestive enzyme activities in aquatic animals: The functional feed additives scenario. Aquaculture Research, v.48, p.3987-4000, 2017. Available from: $<$ https://doi.10.1111/are.13368>. Accessed: May, 10, 2019. doi: 10.1111/are.13368.

HURTADO, M. A. et al. Effect of hypo-and hyper-saline conditions on osmolarity and fatty acid composition of juvenile shrimp Litopenaeus vannamei (Boone, 1931) fed low-and high-HUFA diets. Aquaculture Research, v.37, n.13, p.1316-1326, 2006. Available from: $<$ https://doi.10.1111/j.1365-2109.2006.01568. $\mathrm{x}>$. Accessed: May, 10, 2019. doi: 10.1111/j.13652109.2006.01568.x.

JAIME-CEBALLOS, B. et al. Traslado de postlarvas de Litopenaeus vannamei (Boone, 1931) a diferentes tiempos, salinidades y densidades y su efecto en la supervivencia y algunos marcadores bioquímicos. Revista de Biología Marina y Oceanografía, v.43, p681-686, 2008. Available from: <http:// dx.doi.org/10.4067/S0718-19572008000300027>. Accessed: May, 10, 2019. doi: 10.4067/S0718-19572008000300027.

KIR, M.; KUMLU, M. Effect of temperature and salinity on low thermal tolerance of Penaeus semisulcatus (Decapoda: Penaeidae). Aquaculture Research, v.39, n.10, p.1101-1106, 2008. Available from: <https://doi.10.1111/j.1365-2109.2008.01973.x>. Accessed: May, 10, 2019. doi: 10.1111/j.1365-2109.2008.01973.x.

MARTÍNEZ-CÓRDOVA, L. R. et al. 2009, Camaronicultura Mexicana y Mundial: ¿Actividad sustentable o industria contaminante? Revista Internacional de Contaminación Ambiental., 25 (3), 181-196.

MÉNDEZ-MARTÍNEZ, Y. et al. Effect of different ratios of dietary protein-energy on growth, body proximal composition, digestive enzyme activity, and hepatopancreas histology in Macrobrachium americanum (Bate, 1868) prawn juveniles. Aquaculture, v.485, p.1-11, 2018. Available from: <https://doi.10.1016/j.aquaculture.2017.11.012>. Accessed: May, 10, 2019. doi: 10.1016/j.aquaculture.2017.11.012. 
MÉNDEZ-MARTÍNEZ, Y. et al. Effect of dietary protein content on growth rate, survival and body composition of juvenile cauque river prawn, Macrobrachium americanum (Bate, 1868). Aquaculture Research, v.48, n.3, p.741-751, 2017. Available from: $<$ https://doi.org/10.1111/are.13193>. Accessed: May, 10, 2019. doi: $10.1111 /$ are. 13193

MURPHY, J.; RILEY. J.P. A modified single solution method for the determination of phosphate in natural waters. Analytica Chimica Acta, v.27, p 31-36. 1962. Available from: <https://doi.org/10.1016/ S0003-2670(00)88444-5>. Accessed: May, 31, 2020. doi: 10.1016/ S0003-2670(00)88444-5.

OBALDO, L. G. et al. Method for determining the physical stability of shrimp feeds in water. Aquaculture Research, v.33, n.5, p.369-377, 2002. Available from: <https://doi.org/10.104 6/j.1365-2109.2002.00681.x>. Accessed: May, 10, 2019. doi: 10.1046/j.1365-2109.2002.00681.x.

OLAUSSEN, J. O. Environmental problems and regulation in the aquaculture industry. Insights from Norway, Marine Policy, v.98, p.158-163, 2018. Available from: <https://doi: 10.1016/j. marpol.2018.08.005>. Accessed: May, 10, 2019. doi: 10.1016/j. marpol.2018.08.005.

PALACIOS, E. et al. Survival, $\mathrm{Na}+\mathrm{K}+$ - ATPase and lipid responses to salinity challenge in fed and starved white Pacific shrimp (Litopenaeus vannamei) postlarvae. Aquaculture, v.234, n.1, p.497-511, 2004. Available from: <https://doi.org/10.1016/j. aquaculture.2003.12.001>. Accessed: May, 10, 2019. doi: 10.1016/j.aquaculture.2003.12.001.

PÉREZ-VELÁZQUEZ, M. et al. Investigation of the effects of salinity and dietary protein level on growth and survival of Pacific white shrimp, Litopenaeus vannamei. Journal of the World Aquaculture Society, v.38, n.4, p.475-485, 2007. Available from: $<$ https://doi.org/10.1111/j.1749-7345.2007.00121.x>. Accessed: May, 10, 2019. doi: 10.1111/j.1749-7345.2007.00121.x.

ROSAS, C. et al. Effect of dietary protein and energy levels on growth, oxygen consumption, haemolymph and digestive gland carbohydrates, nitrogen excretion and osmotic pressure of Litopenaeus vannamei (Boone) and L. setiferus (Linne) juveniles (Crustacea, Decapoda; Penaeidae). Aquaculture Research, v.32, n.7, p.531-547, 2001. Available from: $<$ https://doi.org/10.1 046/j.1365-2109.2001.00573.x>. Accessed: May, 10, 2019. doi: 10.1046/j.1365-2109.2001.00573.x.

ROY, L. A. et al. Supplementation of potassium, magnesium and sodium chloride in practical diets for the Pacific white shrimp, Litopenaeus vannamei, reared in low salinity waters. Aquaculture Nutrition, v.13, n.2, p.104-113, 2007. Available from: <https:// doi.org/10.1111/j.1365-2095.2007.00460.x>. Accessed: May, 10, 2019. doi: 10.1111/j.1365-2095.2007.00460.x.

SOLÓRZANO, L. Determination of ammonia in natural waters by the phenol hypochlorite method. Limnology and Oceanography. v.14: p.799-801. 1969 Accessed: May, 31, 2020. doi: 10.4319/ 10.1969.14.5.0799.

VALENZUELA-COBOS， J. D.; VARGAS-FARIAS， C. J. Study about the use of aquaculture binder with tuna attractant in the feeding of white shrimp (Litopenaeus vannamei). Revista Mexicana de Ingeniería Química. v.19, n.1, p.355-361, 2020. Available from: <https://doi.org/10.24275/rmiq/Bio615>. Accessed: May, 31, 2020. doi: 10.24275/rmiq/Bio615.

YANG, Q. et al. Apparent digestibility of selected feed ingredients for white shrimp Litopenaeus vannamei, Boone. Aquaculture Research, v.41, n.1, p.78-86, 2009. Available from: $<$ https://doi.or g/10.1111/j.1365-2109.2009.02307.x>. Accessed: May, 10, 2019. doi: 10.1111/j.1365-2109.2009.02307.x.

ZAR, J. H. Biostatistical analysis. Prentice Hall, Upper Saddle River, New Jersey, 1999. 663p.

ZHU, C. B. et al. The interaction of salinity and $\mathrm{Na} / \mathrm{K}$ ratio in seawater on growth, nutrient retention and food conversion of juvenile Litopenaeus vannamei. Journal of Shellfish Research, v.25, p.107-112, 2006. Available from: $<$ https://doi.org/10.2983/07308000(2006)25[107:TIOSAK]2.0.CO;2>. Accessed: May, 10, 2019. doi: 10.2983/0730-8000(2006)25[107:TIOSAK]2.0.CO;2. 